\title{
VETERINARY MEDICINE
}

DOI https://doi.org/10.30525/978-9934-26-038-4-66

\section{ТЕСТ-МЕТОД ХІМІЧНОГО АНАЛІЗУ РОДАНІДІ У БІОЛОГІЧНИХ РІДИНАХ ДОМАШНІХ ТВАРИН}

\author{
Сябренко К. Г. \\ студент I курсу факультету ветеринарної медицини \\ Національний університет біоресурсів і природокористування Украйни \\ м. Київ, Украӥна
}

Негативний вплив роданіду має суттєве значення для дослідників різних галузей науки, таких як медицина, ветеринарна медицина, хімія харчових продуктів, екологія, біотехнологія, до проблеми розробки нових та удосконалення наявних методик його визначення, а також апробації відомих методик на різноманітних реальних об'єктах. Вміст роданіду в організмі домашніх тварин залежить від багатьох чинників. Нормальна фонова концентрація роданіду потрапляє в організм ссавців 3 їжею та повітрям. Природний вміст роданіду в слині тварин, що не знаходяться в середовищі осіб, які палять, має межі від 0,5 до 2 мМ, а в середовищі курців його концентрація сягає 6 Мм [1, с. 1010]. У сечі та крові детектується нижчий рівень роданіду. Актуальність теми роботи обумовлена необхідністю забезпечення належної якості екологічного моніторингу вмісту роданіду у біологічних рідинах та природних об'єктах, при цьому необхідною умовою $є$ розробка простих, дешевих та експресних методик оцінки вмісту роданіду у зазначених аналітах, які б можна було проводити безпосередньо та швидко в польових умовах [2, с. 5]. Найчастіше для такого дослідження застосовують тестметоди хімічного аналізу. Тест-методи хімічного аналізу - це спрощені прийоми і пристосування для швидкого виявлення і оцінки вмісту тих чи інших компонентів у різних об'єктах, найчастіше у поза лабораторних умовах. [3, с. 160]. 3 огляду на це, визначення роданіду в біологічних об'єктах належать до актуальних проблем сучасної аналітичної хімії та екології людини, тварини й довкілля [4, с. 991, 5, с. 52].

Для дослідження були обрані біологічні рідини, оскільки вміст тіоціонату у слині корелює із вмістом нікотину, а в свою чергу вміст нікотину може слугувати основою для проведення доступних скринінгових обстежень $з$ метою оцінки впливу середовища 3 підвищенним вмістом никотину (пасивне паління), та $є$ однією 3 найважливіших ланок у розв'язанні багатьох екологічних, біологічних проблем людини та тварин. 
Представлена автором методика визначення тіоціонатів у слиниі ссавців та кореляція їх 3 вмістом нікотину заснована на скануванні забарвлених кольорових матриць за допомогою сканера і аналізу одержаного файла зображення за характеристиками кольоровості або відображальною здатністю чи яскравістю.

Дослідження проводили протягом дня, для аналізу використовували нерозбавлену слину. При проведенні аналізу не враховували час прийняття їжі, але враховували час перебування на свіжому повітрі. Заздалегідь виготовлений тест-пристрій поміщають в ротову порожнину, в отвір пробовідборника вносять достатню для аналізу кількість слини. Аналізований компонент (тіоціанат-іон) взаємодіє з реагентами сенсорного елемента з утворенням забарвленого комплексу, за інтенсивністю кольору якого можна робити висновки про вміст роданідів в слині. Для отримання напівкількісного результату необхідно порівняти отриманий колір матриці тест-системи 3 еталонною шкалою. Обгрунтувано можливості сканерної індикації до тест-систем та оцінюванні метрологічних характеристик методик із різними способами індикації (візуальним і сканерним). Враховуючи, що роданіди - стабільні метаболіти, то саме за їх рівнем накопичення у біологічних рідинах (слина, кров) можна визначати інтенсивність метаболізму нікотину.

Таким чином, запропонований в роботі метод вимірювання тіоціанат-іонів в слині як маркерів тютюнопаління є швидким, доступним i може застосовуватися в якості контрольного тесту на наявність та концентрацію роданіду в біологічних рідинах ссавців.

\section{Література:}

1. Nakajima M, Yamamoto T, Nunoya K-I, Yokoi T, Nagashima K, Inoue $\mathrm{K}$ et al. Characterisation of CYP2A6 involved in 3'-hydroxylation of cotinine in human liver microsomes. J. Pharmacol. Exptl. Ther., 1996. №. 277. P. 1010-1015.

2. Gorrod JW. Nicotine: A case study in metabolic complexity. Eur. J. Drug Metab. Pharmacokinet., 1995; Special Issue: 5-9.

3. Мурликіна Н.В., Смірнова І.С. Хімія та експертиза наркотичних, отруйно- небезпечних речовин алкалоїдної природи. Навчальний посібник. /Харк. держ. універс. харч. та торгівлі. - Харків, 2004. 160 с.

4. Brand/inge S, Lindblom L. The enzyme 'aldehyde oxidase' is an iminium oxidase. Reaction with nicotine-hl'(5')-iminium ion. Biochem. Biophys. Res. Comm., 1979. № 91. Р. 991-996.

5. Сябренко К.Г. Обгрунтування, методики аналізу, розробка експресметоду і технологія виготовлення тест-систем для визначення тіоціонатів в біологічних рідинах. Хірургія Донбасу, 2019. Т. 8. № 3.52 с. 